\title{
The Coupled Effect of Temperature and Carbonation on the Corrosion of Rebars in the Simulated Concrete Pore Solutions
}

\author{
Jiezhen Hu, ${ }^{1,2}$ Xuequn Cheng, ${ }^{1}$ Xiaogang Li, ${ }^{1}$ Peichang Deng, ${ }^{3}$ and Gui Wang ${ }^{2}$ \\ ${ }^{1}$ Corrosion and Protection Center, University of Science and Technology Beijing, Beijing 100083, China \\ ${ }^{2}$ Engineering College, Ocean University of Guangdong, Zhanjiang 524088, China \\ ${ }^{3}$ College of Ocean and Meteorology, Ocean University of Guangdong, Zhanjiang 524088, China \\ Correspondence should be addressed to Xiaogang Li; lixiaogang@ustb.edu.cn
}

Received 11 October 2014; Revised 16 February 2015; Accepted 1 March 2015

Academic Editor: Anton Kokalj

Copyright (C) 2015 Jiezhen $\mathrm{Hu}$ et al. This is an open access article distributed under the Creative Commons Attribution License, which permits unrestricted use, distribution, and reproduction in any medium, provided the original work is properly cited.

The reinforced concrete structures have to survive high temperature and carbonation at low latitude region. The research on the effect of temperature and the effect of carbonation are vital to the corrosion of the rebars in concrete structures. The coupled effect of temperature and carbonation on the corrosion of rebars was researched by using the open circuit potential (OCP), the electrochemical impedance spectroscopy (EIS), and the potentiodynamic polarization (PP) measurement in the simulated concrete pore solutions (SPSs). The high temperature environment is conducive to the formation of passivated surface of rebars in SPSs, but the dissolution velocity of passivated surface is higher. The rebars have the greater capacity of passivity at lower temperature. The corrosion rate of rebars at higher temperature is smaller in moderate $\mathrm{pH}$ value (10.6) SPSs. The rebars suffer from serious corrosion in the $\mathrm{pH}=9.6$ SPSs at $318 \mathrm{~K}$ temperature.

\section{Introduction}

Corrosion of rebars in concrete is crucial to the durability of reinforced concrete structure, especially in an aggressive environment. Investigations of the corrosion of rebars in concrete structures are being intensively pursued, because such corrosion can cause serious damage to concrete, and eventually failure of the structure [1]. Carbonation induced corrosion is a major cause of decay of reinforced concrete structures in the fields of buildings, civil engineering bridges, or historical monuments $[2,3]$. The process of carbonation causes a $\mathrm{pH}$ decrease (from around 13 to around 8) in the solution that presents in the concrete pores [4]. As long as the rebars are in a high alkalinity environment concrete, they remain passive. The consumption of portlandite that the natural ageing carbonation process leads to induces the decrease of the $\mathrm{pH}$ of the concrete cover. If the $\mathrm{pH}$ of SPSs reaches a low value, the active corrosion of rebars can take place [2].

Temperature is a key factor in chemical reactions kinetics, including corrosion, obviously. The concrete cover of the rebars is a dynamic system that pore structure and chemical composition change with exposure time to the environment [5]. The presence of $\mathrm{Cl}^{-}, \mathrm{CO}_{2}$, or $\mathrm{SO}_{4}{ }^{2-}$ is frequently cited as the main factors responsible for the onset and propagation of decay [6], that is, cracking due to corrosion of the rebars. Many papers can be found in the literature that describes the phenomenology of the process [7] and the effects of individual factor. However, studies devoted to the coupled effect of temperature and carbonation are rather scarce [8].

The reinforced concrete structures have to survive high temperature and carbonation at low latitude region. A large number of laboratory studies had been conducted, most of which focused on a single factor that impacts the corrosion process such as penetration of $\mathrm{Cl}^{-}$, carbonation of concrete, or loading levels [9-13]. Since reinforced structures generally experience complex environmental and mechanical loadings, there were also a rapidly increasing amount of research into corrosion of rebars in concrete by coupled factors [14-16], but many combined aspects have not yet been examined in sufficient detail. Therefore, the present study is focused on the coupled effect of temperature and carbonation on the corrosion of rebars in SPSs. 
TABLE 1: Chemical composition and nominal $\mathrm{pH}$ of fresh simulated pore solutions.

\begin{tabular}{lccccc}
\hline Composition & $\mathrm{pH}$ & $\mathrm{NaOH}(\mathrm{mol} / \mathrm{L})$ & $\mathrm{KOH}(\mathrm{mol} / \mathrm{L})$ & $\mathrm{Ca}(\mathrm{OH})_{2}(\mathrm{~mol} / \mathrm{L})$ & $\mathrm{NaHCO}_{3}(\mathrm{~mol} / \mathrm{L})$ \\
\hline SPSs1 & 9.6 & 0.6 & 0.2 & 0.001 & 0.39 \\
SPSs2 & 10.6 & 0.6 & 0.2 & 0.001 & 0.16 \\
SPSs3 & 11.6 & 0.6 & 0.2 & 0.1 & 0.84 \\
SPSs4 & 12.6 & 0.6 & 0.2 & 0.001 & 0.76 \\
\hline
\end{tabular}

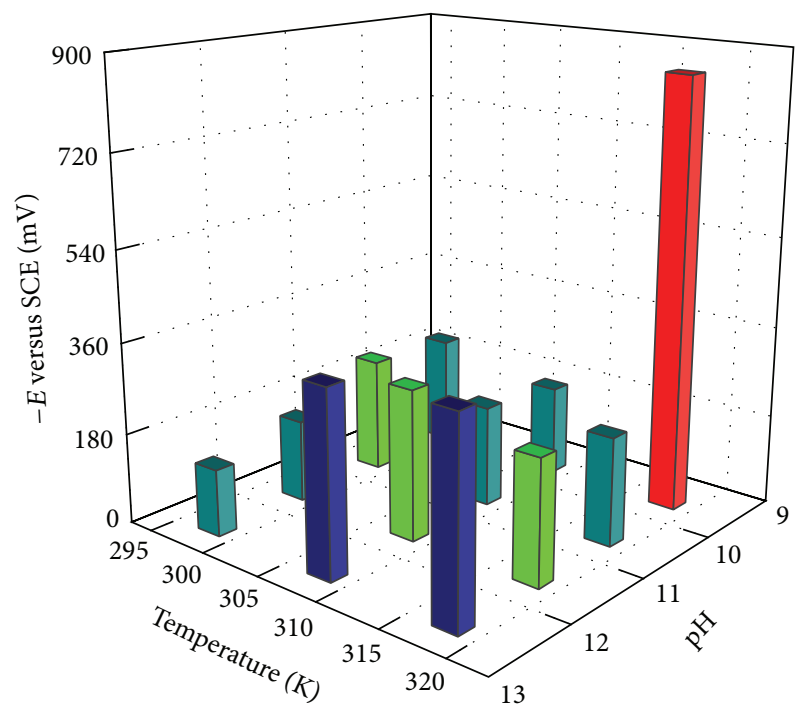

FIgURE 1: The effect of temperature and $\mathrm{pH}$ on the OCP of rebars in SPSs.

\section{Experimental}

2.1. Specimen Preparation. The thread steel bar (HRB400) specimens were prepared for this study. The specimens were cut to $30 \mathrm{~mm}$ lengths from black steel rebar of $12 \mathrm{~mm}$ nominal diameter. The average area of the exposed rebar surfaces (cross section) was $1.1 \pm 0.03 \mathrm{~cm}^{2}$. The unexposed faces were sealed with epoxy resin. Before exposure, the as-received surfaces were mechanically polished using 400, 800, and 1200 emery papers and lubricated using distilled water. The polished samples were cleaned with acetone, washed using distilled water, dried in air, and stored over a desiccant.

2.2. Experimental Setup. A $1 \mathrm{~L}$ glass container was used as a test cell in this study. Four different types of water solutions were selected as the simulated concrete pore solutions (SPSs). The chemical compositions of the SPSs are presented in Table 1 [17]. The lower pH solution was intended to present pore water within a carbonated concrete environment. Approximately $0.8 \mathrm{~L}$ of SPSs was used in each glass container and its $\mathrm{pH}$ was monitored throughout the experiment. Because the results of deviation were less than 0.1 , the effects on experimental results induced by $\mathrm{pH}$ fluctuation were ignored. A magnetic stirring bar was placed at the bottom of each container and was set to rotate at the lowest rate to continuously mix the solution homogeneously throughout the experiment, including the duration when the electrochemical measurements were conducted. Ambient temperature was held at $298 \pm 2 \mathrm{~K}, 308 \pm 2 \mathrm{~K}$, and $318 \pm 2 \mathrm{~K}$.

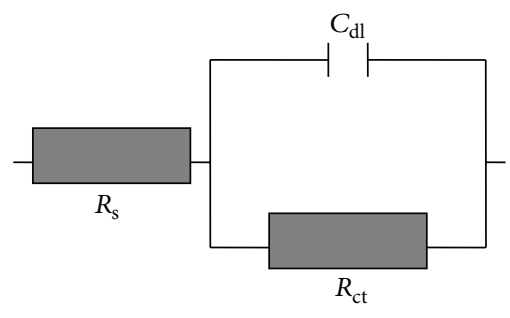

FIgURE 2: Equivalent circuit used in numerical fitting of the impedance data.

2.3. Electrochemical Measurements. For assessing the corrosion conditions of steel bars, the electrochemical measurements were carried out. The rebar was used as working electrode, a platinum net as counter electrode, and a saturated calomel electrode (SCE) as reference electrode. During the course of the experiment, the rebar electrode always was immersed in the SPSs. For the open circuit potential (OCP) measurement, the electrochemical impedance spectroscopy (EIS) measurement, and the potentiodynamic polarization (PP) measurement, Autolab Aut84458 Advanced Potentiostat/Galvanostat/FRA system was applied. The EIS was measured with a sinusoidal potential excitation of $15 \mathrm{mV}$ amplitude in the frequency range from $100 \mathrm{KHz}$ to $10 \mathrm{mHz}$ at corrosion potential. The PP was measured by potential scanning from -800 to $+500 \mathrm{mV}$ versus corrosion potential at a sweep rate of $1 \mathrm{mV} / \mathrm{s}$.

\section{Result and Discussion}

3.1. The Effect of Temperature and $p H$ on the OCP. As can be seen from Figure 1, with the $\mathrm{pH}$ of SPSs rising, the OCP of rebar increases at lower temperature $(298 \mathrm{~K})$ except for the $\mathrm{pH}=10.6$. The OCP of rebar that is immersed in the $\mathrm{pH}=10.6$ SPSs is lowest $(-229 \mathrm{mV})$. The OCP of rebar decreases with $\mathrm{pH}$ of SPSs rising at higher temperature (308 K and $318 \mathrm{~K})$, but the OCP of rebar reduces sharply in $\mathrm{pH}=9.6$ and $318 \mathrm{~K}$ SPSs. The OCP is the reflection of the corrosion tendency of rebar in SPSs. The rebar is prone to corrosion in higher temperature and lower $\mathrm{pH}$ SPSs. The corrosion of rebar is serious in the $\mathrm{pH}=9.6$ and $318 \mathrm{~K}$ SPSs. The rebar has the best corrosionresistance in the $\mathrm{pH}=10.6$ and $318 \mathrm{~K}$ SPSs.

3.2. The Effect of Temperature and $\mathrm{pH}$ on the Passivation Film of Rebar. The passivation film of the rebars was evaluated by EIS. The shape of the EIS spectra can be described by using the RC network depicted in Figure 2. The series resistance $\left(R_{\mathrm{s}}\right)$ accounts for the ionic conduction in the SPSs, whereas the other elements refer to the double layer capacitance at the 

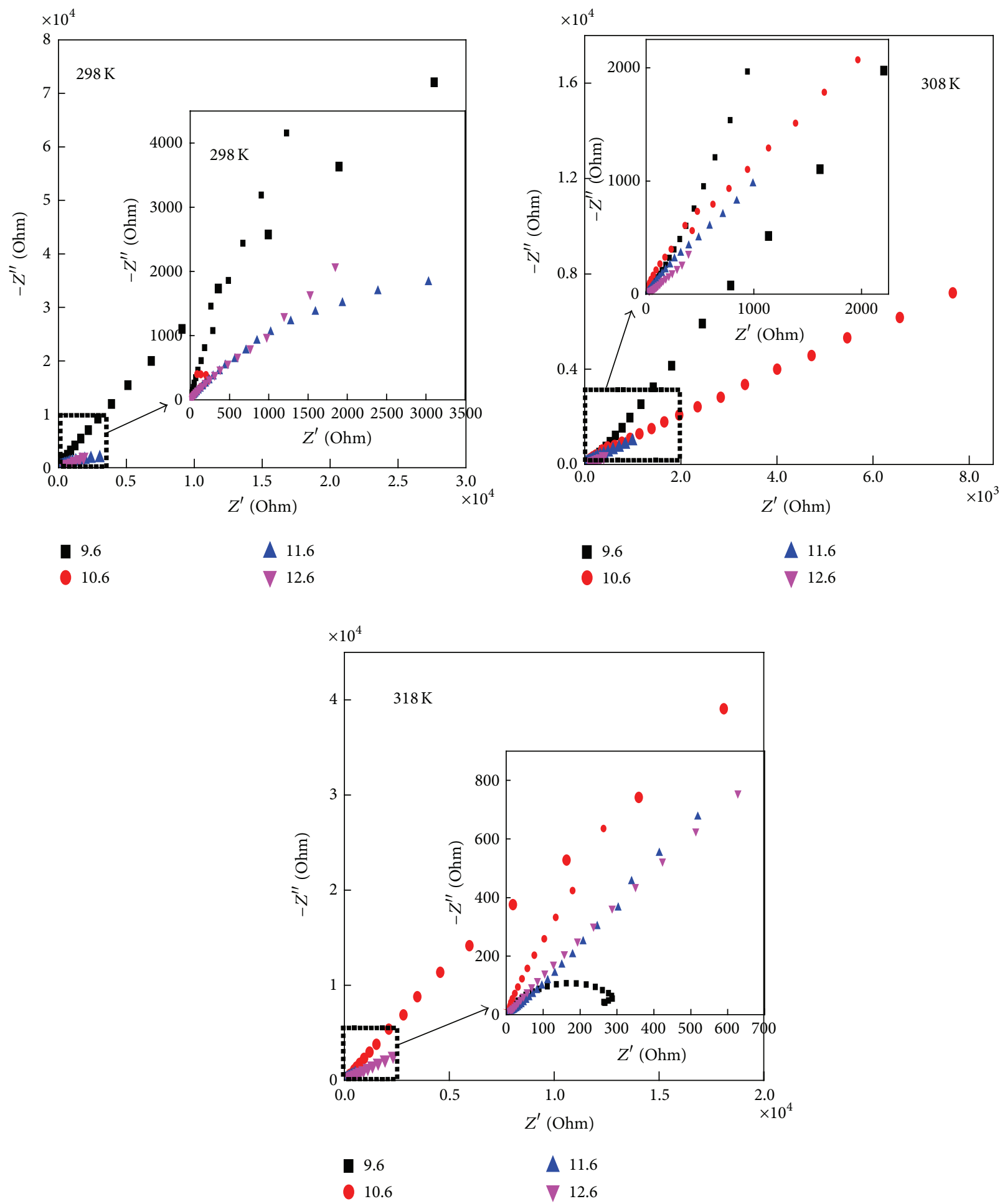

FIgURE 3: The impedance spectra of rebars after 3 days of exposure to the SPSs.

rebar/SPSs interface $\left(C_{\mathrm{dL}}\right)$ and the charge transfer resistance $\left(R_{\mathrm{ct}}\right)$.

Figure 3 depicts the impedance spectra of rebars after 3 days of exposure to the SPSs at $298 \mathrm{~K}, 308 \mathrm{~K}$, and $318 \mathrm{~K}$. At different temperature $(298 \mathrm{~K}, 308 \mathrm{~K}$, and $318 \mathrm{~K})$ and in different $\mathrm{pH}$ value $(9.6,10.6,11.6$ and 12.6) SPSs, the EIS of rebars was measured. The $R_{\mathrm{ct}}$ and $C_{\mathrm{dL}}$, which were obtained from numerical fitting, of the rebars are presented in the Table 2 . The charge transfer resistance is inversely proportional to the corrosion rate [18]. The corrosion rate of rebars at higher temperature is bigger than that at lower temperature. The corrosion rate of rebars at higher temperature is smaller 

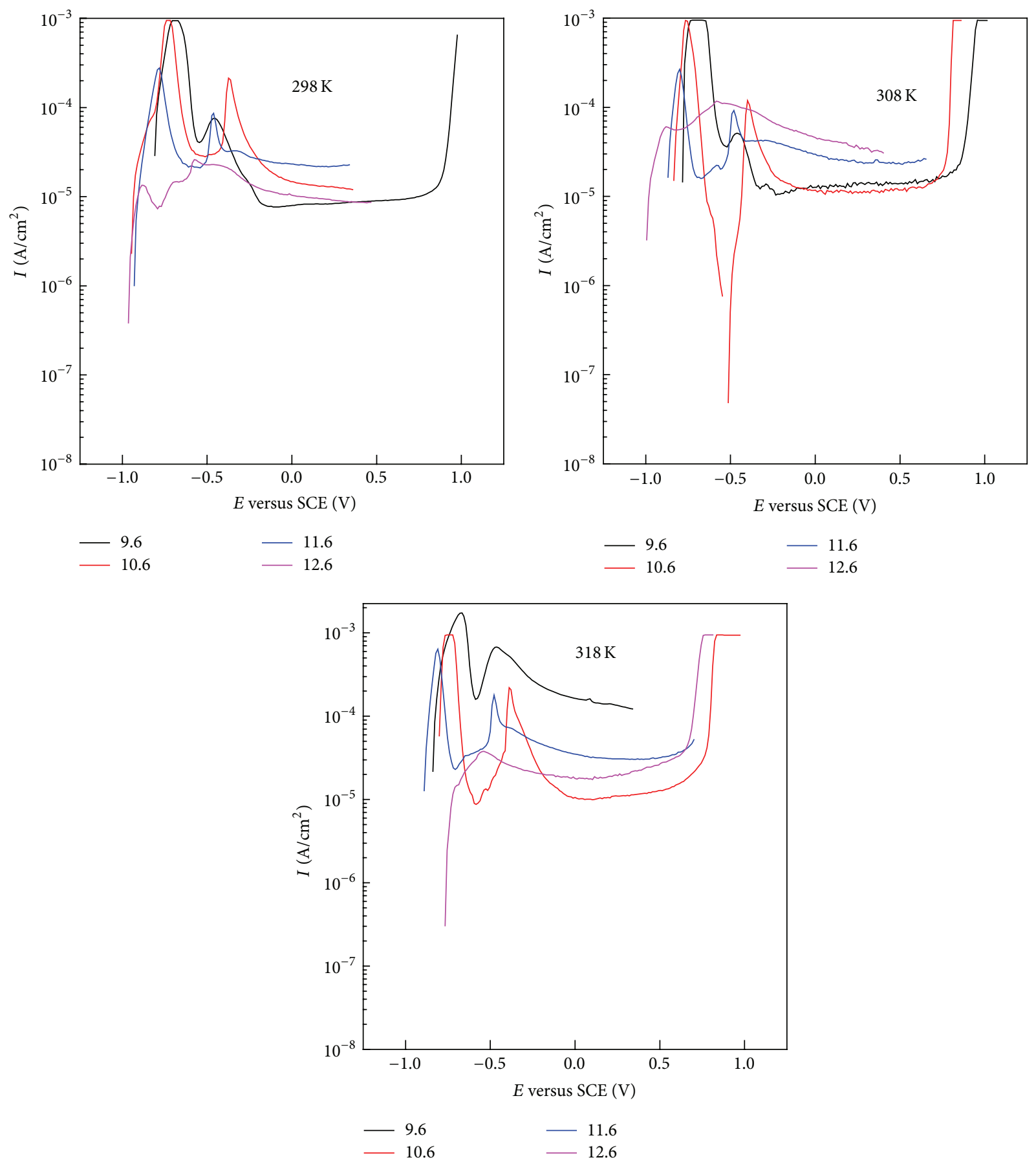

FIgURE 4: The potentiodynamic polarization curves of rebars in different $\mathrm{pH}$ value SPSs.

in moderate $\mathrm{pH}$ value (10.6) SPSs. The capacitive response reveals a situation of passivity for the samples [18]. The rebars have the greater capacity of passivity at lower temperature. It is favourable to passivation that the rebars were soaked in moderate $\mathrm{pH}$ value (11.6) SPSs. The effect of temperature and $\mathrm{pH}$ on the corrosion rate and greater capacity is noteworthy.

3.3. The Effect of Temperature and $p H$ on the Corrosion Current of Rebar. The corrosion current of the rebars, which were soaked in the different $\mathrm{pH}$ and different temperature SPSs, was measured by using potentiodynamic polarization measurements. Figures 4 and 5 represent the potentiodynamic polarization curves of rebars. From Figure 4, the polarization plots of rebars soaked in the lower $\mathrm{pH}$ value $(9.6,10.6$, and 11.6) SPSs exhibited an activation current peak that lie between $-0.5 \mathrm{~V}$ and $-0.25 \mathrm{~V}$. The rebars, which were soaked in higher $\mathrm{pH}$ value (12.6) SPSs, were in the passivation state between $-0.5 \mathrm{~V}$ and $0.75 \mathrm{~V}$. The passive current of rebars 

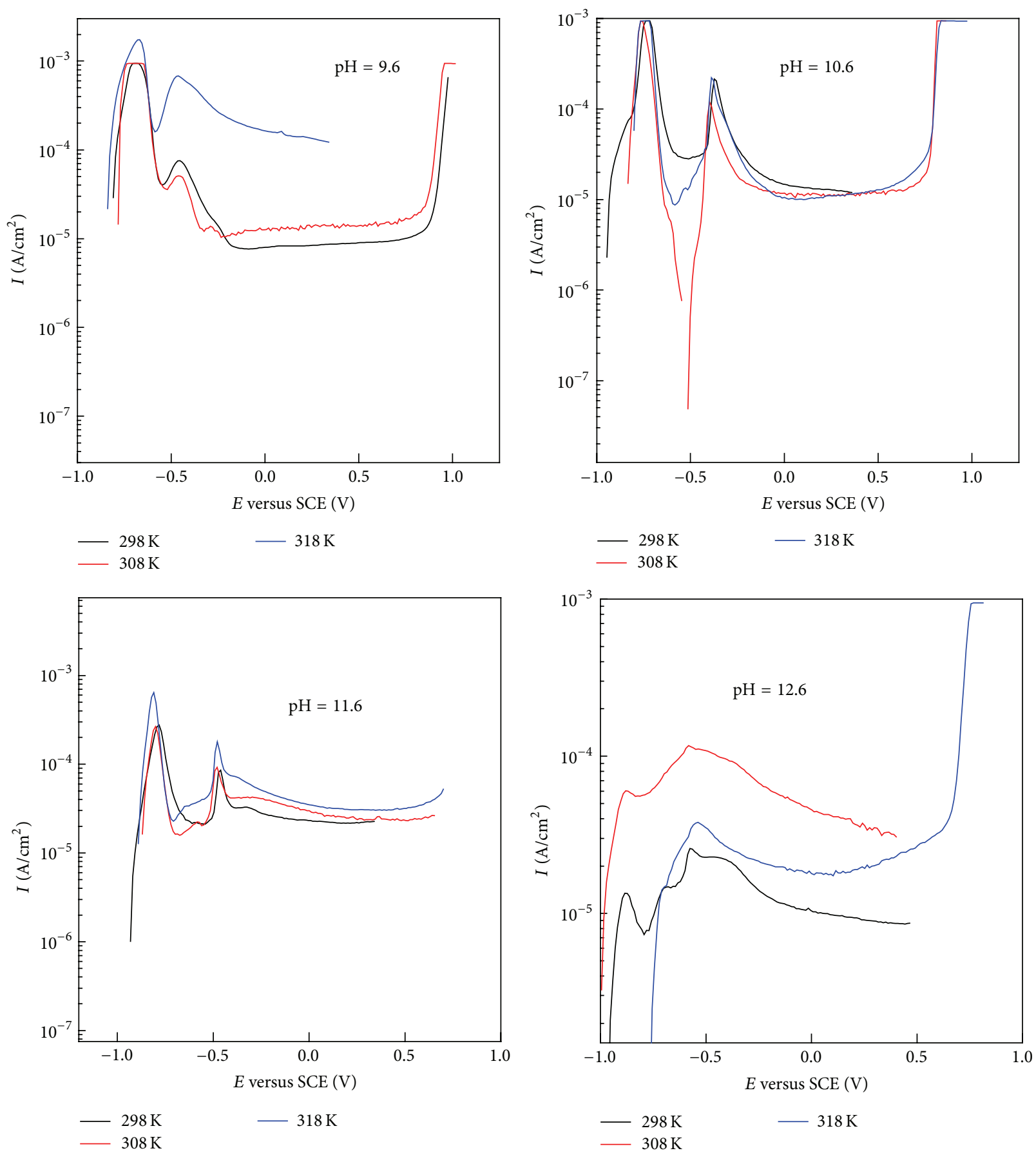

FIGURE 5: The potentiodynamic polarization curves of rebars at different temperature.

in the higher $\mathrm{pH}$ value SPSs is bigger than that of rebars in lower $\mathrm{pH}$ value SPSs. This means that the dissolution velocity of passivated surface is bigger if the $\mathrm{pH}$ of the SPSs is very high. From Figure 5, the high temperature environment is conducive to the formation of passivated surface. At $318 \mathrm{~K}$ temperature, the rebars suffer from serious corrosion in the $\mathrm{pH}=9.6$ SPSs and the rebars have the strong corrosion resistance in the $\mathrm{pH}=10.6$ SPSs. This means that the high temperature and high $\mathrm{pH}$ environment are conducive to the formation of passivated surface. The potentiodynamic polarization results also support the findings of EIS studies.

\section{Conclusions}

The reinforced concrete structures have to survive high temperature and carbonation at low latitude region. The research 
TABLE 2: The $R_{\mathrm{ct}}$ and $C_{\mathrm{dl}}$ obtained from numerical fitting of the rebars.

\begin{tabular}{lcccccc}
\hline \multirow{2}{*}{$\mathrm{pH}$} & \multicolumn{3}{c}{$R_{\mathrm{ct}}(\mathrm{Ohm})$} & \multicolumn{3}{c}{$C_{\mathrm{dl}}(\mu \mathrm{Mho})$} \\
& $298 \mathrm{~K}$ & $308 \mathrm{~K}$ & $318 \mathrm{~K}$ & $298 \mathrm{~K}$ & $308 \mathrm{~K}$ & $318 \mathrm{~K}$ \\
\hline 9.6 & 8790 & 865 & 251 & 87 & 262 & 1320 \\
10.6 & 619 & 1850 & 3290 & 762 & 122 & 139 \\
11.6 & 543 & 488 & 48 & 644 & 2290 & 1330 \\
12.6 & 1190 & 106 & 173 & 1940 & 1880 & 637 \\
\hline
\end{tabular}

on the coupled effect of temperature and carbonation is vital to the corrosion of the rebars in concrete structures. The results presented above allow to us conclude the following.

(1) The high temperature environment is conducive to the formation of passivated surface of rebars in the simulated concrete pore solutions. But the dissolution velocity of passivated surface is bigger in the high temperature SPSs. The rebars have the greater capacity of passivity at lower temperature.

(2) The rebars soaked in the lower $\mathrm{pH}$ value $(9.6,10.6$, and 11.6) SPSs exhibit an activation process. In the higher $\mathrm{pH}$ value (12.6) SPSs, the rebars were always in the passivation state; however, the passive current is not smallest. The corrosion rate of rebars is smallest in moderate $\mathrm{pH}$ value (10.6) SPSs at higher temperature. The rebars suffer from serious corrosion in the $\mathrm{pH}=$ 9.6 SPSs at $318 \mathrm{~K}$ temperature.

\section{Conflict of Interests}

The authors declare that there is no conflict of interests regarding the publication of this paper.

\section{Acknowledgment}

The authors gratefully acknowledge financial support from National Basic Research Program of China (973 Program) (no. 2014CB643300).

\section{References}

[1] Z. Wang, Q. Zeng, L. Wang, Y. Yao, and K. Li, "Corrosion of rebar in concrete under cyclic freeze-thaw and Chloride salt action," Construction and Building Materials, vol. 53, pp. 40-47, 2014.

[2] Y. Tong, V. Bouteiller, E. Marie-Victoire, and S. Joiret, "Efficiency investigations of electrochemical realkalisation treatment applied to carbonated reinforced concrete-part 1: sacrificial anode process," Cement and Concrete Research, vol. 42, no. 1, pp. 84-94, 2012.

[3] L. Bertolini, M. Carsana, and E. Redaelli, "Conservation of historical reinforced concrete structures damaged by carbonation induced corrosion by means of electrochemical realkalisation," Journal of Cultural Heritage, vol. 9, no. 4, pp. 376-385, 2008.

[4] G. Trabanelli, C. Monticelli, V. Grassi, and A. Frignani, "Electrochemical study on inhibitors of rebar corrosion in carbonated concrete," Cement and Concrete Research, vol. 35, no. 9, pp. 1804-1813, 2005.
[5] J. M. Deus, B. Díaz, L. Freire, and X. R. Nóvoa, "The electrochemical behaviour of steel rebars in concrete: an Electrochemical Impedance Spectroscopy study of the effect of temperature," Electrochimica Acta, vol. 131, pp. 106-115, 2014.

[6] B. J. Magee, P. A. M. Basheer, Y. Bai et al., "UK-China Science Bridge-sustainable solutions for the built environment," Construction and Building Materials, vol. 47, pp. 20-28, 2013.

[7] C. G. Nogueira and E. D. Leonel, "Probabilistic models applied to safety assessment of reinforced concrete structures subjected to chloride ingress," Engineering Failure Analysis, vol. 31, pp. 7689, 2013.

[8] A. Michel, P. V. Nygaard, and M. R. Geiker, "Experimental investigation on the short-term impact of temperature and moisture on reinforcement corrosion," Corrosion Science, vol. 72, pp. 26-34, 2013.

[9] A. Nasser, A. Clément, S. Laurens, and A. Castel, "Influence of steel-concrete interface condition on galvanic corrosion currents in carbonated concrete," Corrosion Science, vol. 52, no. 9, pp. 2878-2890, 2010.

[10] A. Ababneh and M. Sheban, "Impact of mechanical loading on the corrosion of steel reinforcement in concrete structures," Materials and Structures, vol. 44, no. 6, pp. 1123-1137, 2011.

[11] X. G. Feng, Y. M. Tang, and Y. Zuo, "Influence of stress on passive behaviour of steel bars in concrete pore solution," Corrosion Science, vol. 53, no. 4, pp. 1304-1311, 2011.

[12] Z. H. Dong, W. Shi, and X. P. Guo, "Initiation and repassivation of pitting corrosion of carbon steel in carbonated concrete pore solution," Corrosion Science, vol. 53, no. 4, pp. 1322-1330, 2011.

[13] X. M. Shi, N. Xie, K. Fortune, and J. Gong, "Durability of steel reinforced concrete in chloride environments: an overview," Construction and Building Materials, vol. 30, pp. 125-138, 2012.

[14] T. A. Söylev and M. G. Richardson, "Corrosion inhibitors for steel in concrete: state-of-the-art report," Construction and Building Materials, vol. 22, no. 4, pp. 609-622, 2008.

[15] J. H. Jiang and Y. S. Yuan, "Development and prediction strategy of steel corrosion rate in concrete under natural climate," Construction and Building Materials, vol. 44, pp. 287-292, 2013.

[16] A. Alhozaimy, R. R. Hussain, R. Al-Zaid, and A. Al-Negheimish, "Coupled effect of ambient high relative humidity and varying temperature marine environment on corrosion of reinforced concrete," Construction and Building Materials, vol. 28, no. 1, pp. 670-679, 2012.

[17] C. J. Kitowski and H. G. Wheat, "Effect of chlorides on reinforcing steel exposed to simulated concrete solutions," Corrosion, vol. 53, no. 3, pp. 216-226, 1997.

[18] M. F. Montemor, M. P. Cunha, M. G. Ferreira, and A. M. Simões, "Corrosion behaviour of rebars in fly ash mortar exposed to carbon dioxide and chlorides," Cement and Concrete Composites, vol. 24, no. 1, pp. 45-53, 2002. 

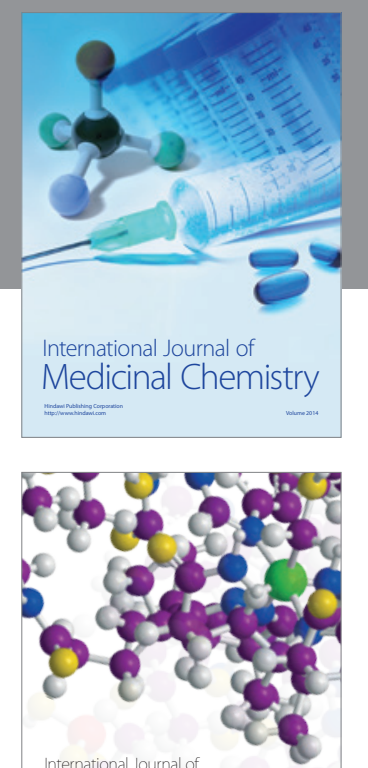

\section{Carbohydrate} Chemistry

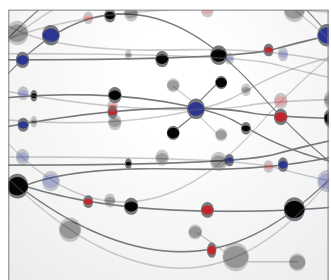

The Scientific World Journal
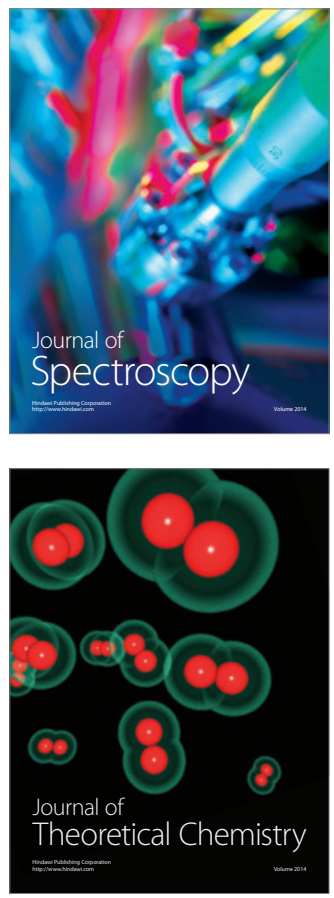
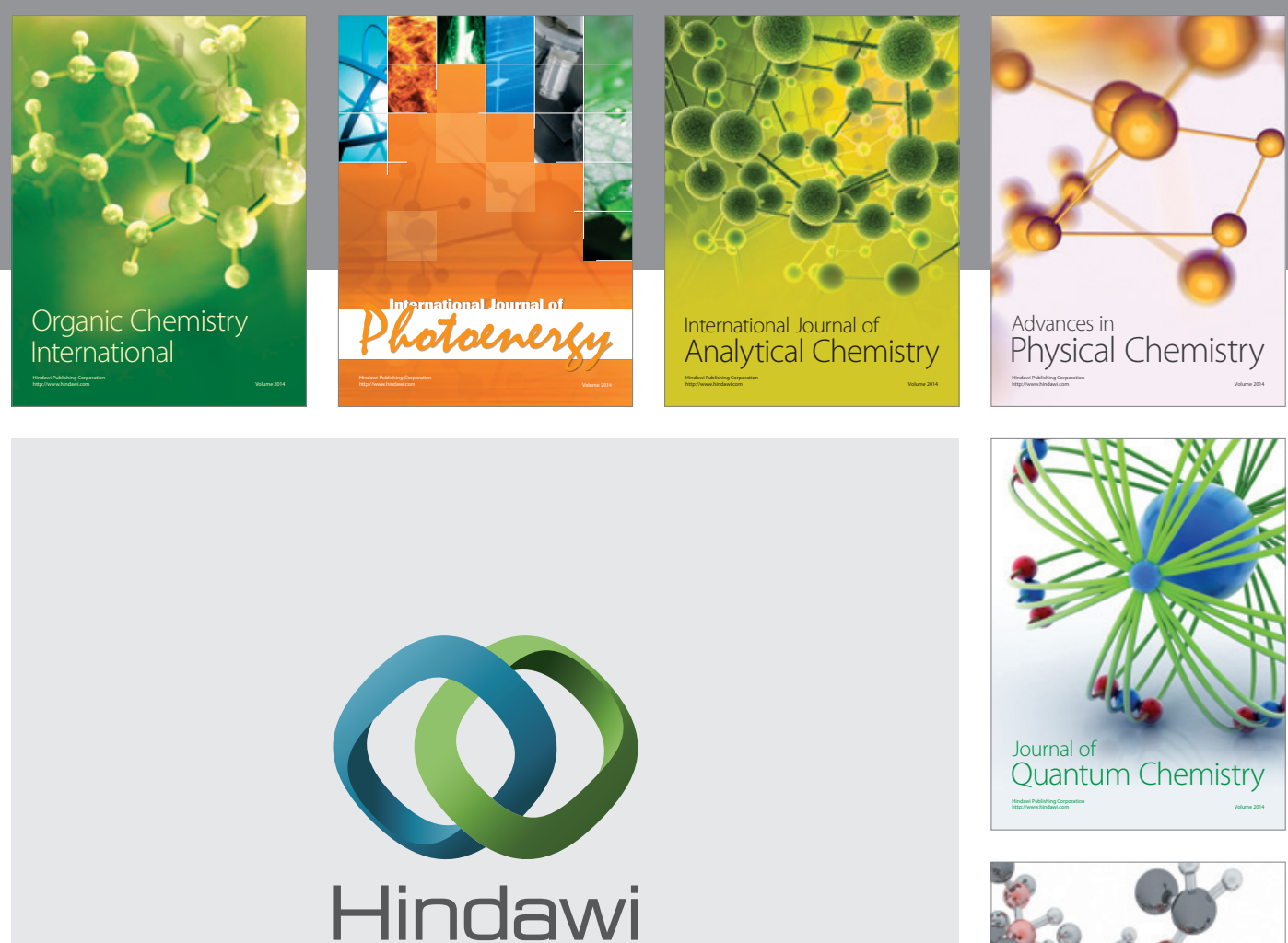

Submit your manuscripts at

http://www.hindawi.com

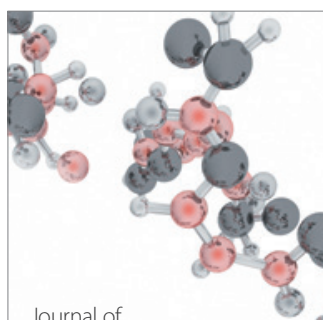

Analytical Methods

in Chemistry

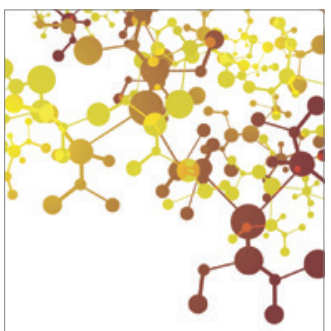

Journal of

Applied Chemistry

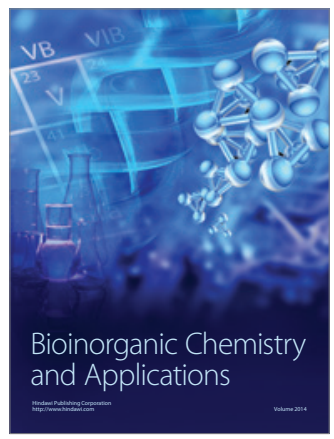

Inorganic Chemistry
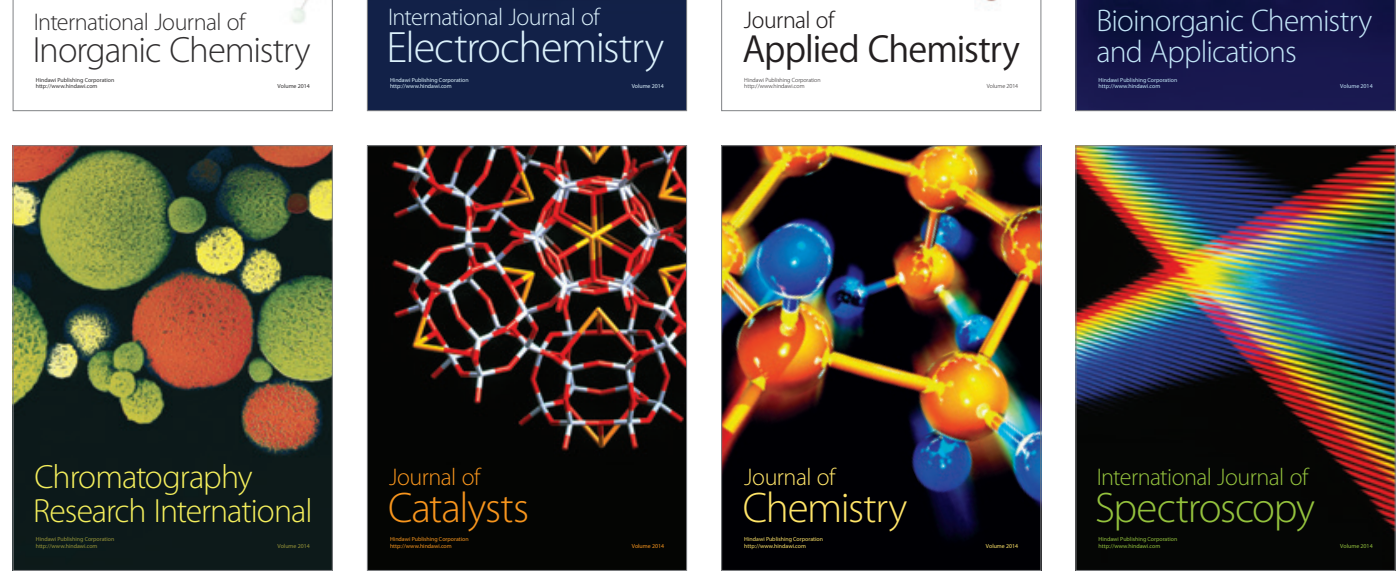